\title{
CRESCIMENTO URBANO, SALDOS MIGRATÓRIOS E ATRATIVIDADE RESIDENCIAL \\ Dos Distritos da Cidade de São Paulo: 1980-2000
}

\author{
PAULO DE MARTINO JANNUZZI \\ NiCOLÁO J A N N UZZ I
}

R E S U M O Esse trabalho procura contribuir para a análise das mudanças recentes no padrão redistributivo da população dentro do município de São Paulo. Apresenta as tendências de crescimento demográfico dos 96 distritos paulistanos de 1980 a 2000 e sua aderência à tese de crescimento radiocêntrico, do centro para a periferia, proposta na literatura como padrão histórico da distribuição espacial no século XX. Por meio de um modelo demográfico, são quantificados os saldos migratórios e coeficientes de atratividade residencial dos referidos distritos. Procura explicar as tendências observadas com base em fatores fisico-territoriais, socioespaciais e econômico-urbanos, mostrando como as deseconomias da aglomeração, pauperização, verticalização, avanço do comércio, produzem impactos diferenciados no crescimento intra-urbano, potencializando os fluxos de ou para determinadas áreas no município.

P A L A V R A S - C H A V E Crescimento urbano; mobilidade residencial; município de São Paulo; economia urbana; migração.

\section{APRESENTAÇÃO}

A diminuição dos fluxos migratórios em direção à Região Metropolitana de São Paulo e a evasão populacional de seu município-sede têm sido um dos fenômenos mais destacados entre as mudanças observadas na dinâmica migratória pelo País a partir dos anos $80 .{ }^{1}$ A análise das mudanças no padrão redistributivo da população dentro do município de São Paulo, contudo, não têm merecido igual atenção, em que pese seu porte, sua importância econômica e a pertinência desse tipo de informação para fins de planejamento urbano.

Esse trabalho procura contribuir ao preenchimento dessa lacuna, analisando as tendências de crescimento intra-urbano da capital paulista de 1980 a 2000, tomando como unidades de análise os distritos instalados na nova divisão administrativa adotada nos anos 90 .

Inicialmente, depois de rápida recuperação das tendências históricas de crescimento populacional do município de São Paulo, apresenta-se uma análise das tendências de crescimento demográfico distrital nas duas últimas décadas. Em seguida, com base em um modelo demográfico, computa-se os saldos migratórios e coeficientes de atratividade residencial dos 96 distritos paulistanos. Procura-se, então, explicar as ten- 
dências observadas baseadas em fatores físico-territoriais, socioespaciais e econômicourbanos, mostrando como as deseconomias da aglomeração, pauperização, verticalização, avanço do comércio, efeitos decorrentes das obras públicas, produzem impactos diferenciados na redistribuição intra-urbana da população, potencializando os fluxos de ou para determinadas áreas no município. Traz-se, ainda, em apêndices, descrição do modelo matemático usado no cálculo da atratividade urbana, tabela com informações demográficas e sociais dos distritos no período e mapa com a divisão territorial da capital.

\section{TENDÊNCIAS DO CRESCIMENTO DEMOGRÁFICO DISTRITAL: $1980-2000$}

Para se entender o quadro atual da ocupação e crescimento intra-urbano no município de São Paulo é interessante recuperar alguns elementos gerais de sua dinâmica populacional no século XX, desde seu vertiginoso ritmo de crescimento demográfico nos primeiros cinqüenta anos, seu transbordamento para os municípios vizinhos, e a reversão da polarização do crescimento da metrópole em direção ao interior (Rolnik et al., 1990).

Para ilustrar o primeiro momento basta citar que, de 1900 a 1950, a população de São Paulo aumentou em mais de nove vezes, passando de cerca de 240 mil habitantes para 2,2 milhōes. Em termos médios, isso representou uma taxa de crescimento de 4,5\% anuais. Foi um processo extremamente rápido, alimentado por numerosos contingentes de migrantes do interior do Estado, de Minas Gerais, de Estados do Nordeste e mesmo de imigrantes italianos, portugueses, espanhóis, japoneses etc).

A partir de então, o cinturão de cidades vizinhas passou a crescer a um ritmo ainda mais acelerado, dando início ao processo de periferização da população em direção a municípios cada vez mais distantes da capital.

Gráfico 1 - Taxas anuais de crescimento populacional (\%) - Estado, Região Metropolitana e Município de São Paulo, 1940-2000.

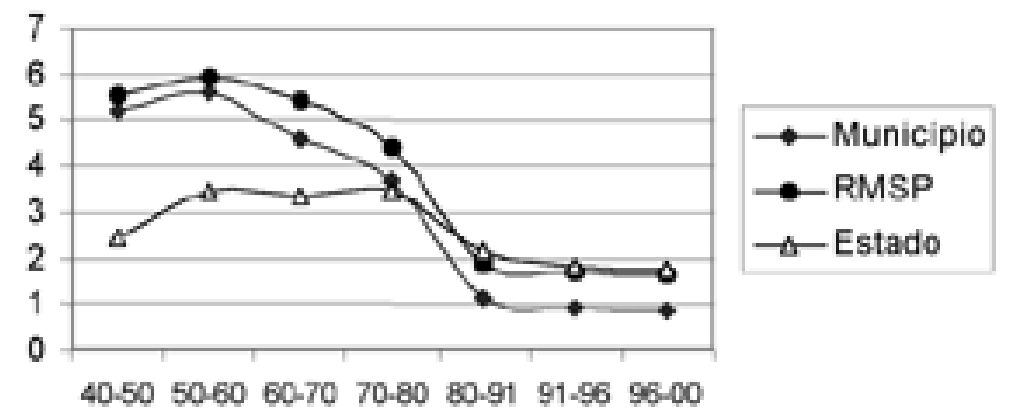

Já nos anos 60, algumas regiōes do interior paulista passaram a disputar a primazia do crescimento urbano com a Região Metropolitana então constituída. A população do município de São Paulo, que ainda crescia a 3,7\% ao ano na década de 1970, apresentou uma forte queda no ritmo de crescimento na década seguinte ( $1,2 \%$ ao ano), passando a registrar, pela primeira vez em sua história recente, saldos migratórios negativos. Nos anos 90, o ritmo de crescimento demográfico permaneceu baixo, sinalizando a con- 
tinuidade do processo de evasão populacional do município. De fato, pelos resultados preliminares do Censo 2000, a taxa média anual de crescimento populacional entre 1991 e 2000 foi abaixo de $0,9 \% .^{2}$

Tabela 1 - População e taxas anuais de crescimento populacional (\%) - Estado, Região Metropolitana e Município de São Paulo, 1940-2000

\begin{tabular}{lllllll}
\hline Ano & $\begin{array}{l}\text { Município } \\
\text { de São } \\
\text { Paulo }\end{array}$ & $\begin{array}{l}\text { Taxa } \\
\text { média } \\
\text { aa }\end{array}$ & $\begin{array}{l}\text { Região Me- } \\
\text { tropolitana } \\
\text { de São Paulo }\end{array}$ & $\begin{array}{l}\text { Taxa } \\
\text { média } \\
\text { aa }\end{array}$ & $\begin{array}{l}\text { Estado } \\
\text { de São } \\
\text { Paulo }\end{array}$ & $\begin{array}{l}\text { Taxa } \\
\text { média } \\
\text { aa }\end{array}$ \\
\hline 1940 & 1.326 .261 & 5,18 & 1.568 .045 & 5,54 & 7.180 .316 & 2,44 \\
1950 & 2.198 .096 & 5,58 & 2.688 .901 & 5,95 & 9.134 .423 & 3,45 \\
1960 & 3.781 .446 & 4,59 & 4.791 .245 & 5,44 & 12.823 .806 & 3,32 \\
1970 & 5.924 .615 & 3,65 & 8.139 .730 & 4,42 & 17.771 .948 & 3,45 \\
$1980^{*}$ & 8.475 .380 & 1,15 & 12.549 .856 & 1,86 & 24.953 .238 & 2,12 \\
$1991^{*}$ & 9.610 .659 & 0,89 & 15.369 .305 & 1,67 & 31.436 .273 & 1,82 \\
$1996 \#^{*}$ & 10.044 .787 & 0,87 & 16.694 .651 & 1,63 & 34.407 .358 & 1,77 \\
$2000^{*}$ & 10.398 .576 & - & 17.807 .926 & - & 36.909 .200 & - \\
\hline
\end{tabular}

Fonte: Rolnik et al. (1990), Censo Demográfico 1991; Contagem Populacional 1996. Fundação Seade; Censo Demográfico 2000 - resultados preliminares.

Nota: * População ajustada para primeiro de julho; \# População corrigida em função de subenumeração diferencial da contagem.

Ao longo desses três momentos da dinâmica demográfica paulistana no século XX, a paisagem urbana teria passado, segundo Lagenbuch (1971), por níveis crescentes de compactação da área edificada, pela verticalização e expansão territorial da zona urbana. ${ }^{3}$ Esses processos se deram progressivamente do Centro e bairros próximos (Santa Ifigênia, Santa Cecília, Liberdade, Paraíso, Aclimação) para bairros mais afastados (Santana, Penha, Lapa e Pinheiros), com a ocupação dos terrenos baldios (Jardim Europa, Sumaré, Vila Clementino) e dos "vazios" existentes entre loteamentos construídos nas décadas anteriores (Planalto Paulista, Sumarezinho, Jardim das Bandeiras), estendendo-se para os núcleos suburbanos estabelecidos ao longo das ferrovias e vias de circulação rodoviária, expandindo a mancha urbana da capital.

Como observa Rolnik (2000), tal padrão radiocêntrico de expansão da cidade havia se configurado a partir dos anos 20 e 30, seguindo a lógica da concepção urbanística de Prestes Maia (e das intervenções urbanas que se seguiram nas décadas posteriores) e a lógica da exclusão social a que os trabalhadores imigrantes estavam sujeitos ao aportar na capital. Os custos para a aquisição de terrenos e dos aluguéis das áreas já urbanizadas (muitas já em processo de verticalização) forçavam a ocupação territorial cada vez mais periférica do município, em loteamentos irregulares e por meio da autoconstrução.

Assim, na década de 1960, a região anelar mais periférica da cidade, compreendendo a Zona Leste, Zona Noroeste (Jaraguá e adjacências) e sul de Santo Amaro, cresceu cerca de $13 \%$ ao ano, respondendo por $43 \%$ do crescimento demográfico paulistano. As áreas adjacentes a esse anel externo, internas ao município, também cresceram a taxas elevadas ( $5,5 \%$ ao ano), respondendo por outros $41 \%$ do incremento de população no município (Rolnik et al., 1990). Os bairros centrais, contudo, cresciam a menos de $1 \%$ ao ano, indicando um processo de evasão populacional e diminuição da densidade demográfica de população residente.
2 A população enumerada na Contagem Populacional de 1996 era de 9.839 .066 pessoas para o município de São Paulo. Contudo, parece haver certo consenso entre especialistas que a Contagem Populacional de 1996 apresentou uma subenumeração de população mais alta a que os Censos Demográficos normalmente têm estado sujeitos no País. Assim, a população do município de São Paulo foi corrigida por um fator de $2,1 \%$, cifra que parece introduzir uma correção adequada às tendências de crescimento demográfico na década de 1990, pelo que sugerem os resultados preliminares do Censo 2000. Correção de mesma magnitude foi aplicada para a Região Metropolitana de São Paulo. No caso do Estado tomou-se as estimativas corrigidas da Fundação Seade, disponíveis em seu sítio na Internet. Vale notar que a correção implementada pela Fundação Seade aos dados da Contagem para o município de São Paulo foram de 1,9\%. Cabe observar ainda que, na falta de parâmetros externos confiáveis, o fator de correção da população foi o mesmo para todos os distritos (o que implica que os incrementos absolutos foram proporcionais ao volume populacional distrital). Tal procedimento não parece comprometer a análise das tendências espaciais do fenômeno, mas podem levantar questionamentos em relação à magnitude das taxas de crescimento distrital e dos saldos migratórios apresentados mais à frente no texto.

3 Entre 1930 e 1970, Rolnik (1990) aponta que a densidade populacional da área central teria permanecido estável, contrapondo-se ao apontado por Langenbuck (1971). 
Nos anos 70 essas tendências se mantiveram, mas a um ritmo de crescimento menos acentuado nas áreas mais periféricas e com certa recuperação das áreas centrais, como resultado combinado de dois processos de sentidos opostos: a continuidade do movimento de ocupação de loteamentos populares e autoconstrução na periferia, de um lado, e o encortiçamento em direção às áreas centrais, de outro (Rolnik et al., 1990).

A resultados semelhantes chegam Bógus \& Taschner (2001), ao analisar o crescimento urbano do município de 1960 a 1996. Pelo agrupamento dos distritos da capital em quatro anéis adjacentes (interior, intermediário, exterior e periférico), que se sucedem em torno de uma região central, as autoras mostram que as taxas de crescimento demográfico vão tornando-se menores e negativas na região central, tendência que vai propagando-se sucessivamente para os anéis circundantes mais próximos, enquanto os anéis mais externos passam a exibir taxas de expansão mais elevadas.

Tabela 2 - População e taxas anuais de crescimento populacional (\%) segundo grandes áreas - Município de São Paulo, 1980-2000

\begin{tabular}{|c|c|c|c|c|c|c|c|}
\hline \multirow[t]{3}{*}{$\overline{\text { Área }}$} & \multirow[t]{3}{*}{1980} & \multirow[t]{3}{*}{1991} & \multirow[t]{3}{*}{$1996^{*}$} & \multirow[t]{3}{*}{2000} & \multicolumn{3}{|c|}{ Taxa média anual (\%) } \\
\hline & & & & & $1980-$ & $1991-$ & 1996- \\
\hline & & & & & 1991 & 1996 & 2000 \\
\hline$\overline{\text { Distritos centrais }}$ & 588.933 & 511.618 & 445.680 & 411.896 & $-1,27$ & $-2,72$ & $-1,95$ \\
\hline Distritos próximos & 3.946 .509 & 4.066 .590 & 3.988 .097 & 3.888 .389 & 0,27 & $-0,39$ & $-0,63$ \\
\hline Leste 1 & 1.525 .062 & 1.554 .397 & 1.502 .597 & 1.488 .370 & 0,17 & $-0,68$ & $-0,24$ \\
\hline Norte 1 & 883.929 & 927.279 & 940.904 & 1.020 .976 & 0,44 & 0,29 & 2,06 \\
\hline Sul 1 & 650.213 & 648.979 & 634.700 & 626.706 & $-0,02$ & $-0,44$ & $-0,32$ \\
\hline Oeste & 887.305 & 935.935 & 909.895 & 752.336 & 0,49 & $-0,56$ & $-4,64$ \\
\hline Distritos periféricos & 3.939 .941 & 5.032 .451 & 5.611 .010 & 6.098 .291 & 2,25 & 2,20 & 2,10 \\
\hline Leste 2 & 1.147 .129 & 1.682 .036 & 1.934 .905 & 2.158 .112 & 3,54 & 2,84 & 2,77 \\
\hline Norte 2 & 902.756 & 1.037 .681 & 1.139 .735 & 1.203 .034 & 1,27 & 1,89 & 1,36 \\
\hline Sul 2 & 1.890 .056 & 2.312 .734 & 2.536 .369 & 2.737 .145 & 1,85 & 1,86 & 1,92 \\
\hline Total & 8.475 .383 & 9.610 .659 & 10.044 .787 & 10.398 .576 & 1,15 & 0,89 & 0,87 \\
\hline
\end{tabular}

Fonte: Censos Demográficos 1991 e 2000, Contagem Populacional 1996.

Nota: * População corrigida em função de subenumeração diferencial da contagem.

A análise dos dados de crescimento demográfico distrital nos anos 90 revela a continuidade do processo de periferização da população no município (vide dados trazidos em Apêndice). As taxas de crescimento dos distritos centrais passam a ser não apenas mais baixas como também negativas, denotando uma forte evasão de população residente nos

40 termo "esvaziamento" é certamente um tanto inadequado para ser usado nesse contexto, dados os enormes contingentes populacionais ainda residentes nos distritos centrais e o ritmo em que o processo está se dando (taxas negativas inferiores a $5 \%$ em geral). Mas talvez seja um termo mais simples para denotar um processo ao longo do tempo e espaço que outros como "decremento" ou "decrescimento" populacional. bairros centrais e de ocupação mais antiga. Nos anos 80, dos 96 distritos paulistanos 41 apresentaram diminuição absoluta de população residente; entre 1996 e 2000, esse número aumentou para 56, ao incorporar outros distritos localizados em região menos central. Observa-se, pois, um movimento de "esvaziamento" populacional absoluto em ritmo crescente no tempo e no espaço se processando a partir dos distritos mais centrais. ${ }^{4}$

A natureza crescente do processo de "esvaziamento" pode ser ilustrado, por exemplo, pelo comportamento observado nos distritos da Sé, Brás e Santa Cecília: nos anos 80 esses distritos apresentavam taxas anuais de crescimento negativas em torno de $1 \%$ a 2\%; entre 1991 e 1996, as taxas passaram a situar-se entre valores negativos acima de $2 \%$ ao ano. O espraiamento espacial do processo pode ser atestado pelo comportamento dos distritos do Limão, Freguesia do Ó e Moema, mais afastados do centro, mas 
de ocupação antiga na capital, que passaram a ostentar crescimento demográfico negativo nos anos 90, depois de apresentar taxas baixas de crescimento na década de $80 \mathrm{Na}$ periferia, por outro lado, as taxas de crescimento de alguns distritos mantiveram-se altas ou até mesmo se elevaram no período, em alguns casos, em que pese a continuidade da redução da taxa de crescimento demográfico do município. Nesse contexto, vale observar as tendências divergentes dos distritos periféricos de Anhanguera e Cidade Tiradentes: no primeiro caso a taxa de crescimento anual dobrou dos anos 80 para o primeiro qüinqüênio da década de 90 (de $8 \%$ para $18 \%$ ao ano); no segundo, a taxa teve forte queda no período, mas manteve-se ainda alta em relação à dos demais distritos (de 25\% para $11 \%$ ao ano no período).

Na segunda metade da década passada, de 1996 a 2000, ainda que as tendências gerais permaneçam, há algumas nuanças a destacar: arrefecimento da evasão dos distritos centrais (que mantêm taxas negativas, mas um pouco menores em módulo que no qüinqüênio anterior); volta do crescimento demográfico de alguns distritos próximos que antes perdiam população; e diminuição das taxas de expansão dos distritos periféricos (todos com taxas anuais inferiores a 9\%). No primeiro caso, destaca-se o Pari, que perdia população a uma taxa de quase $6 \%$ ao ano entre 1991 e 1996 e que veio a ter um decréscimo de cerca de $2 \%$ ao ano na segunda metade da década passada. Entre os distritos menos centrais mas não muito distantes que apresentaram uma inversão de tendência (de decréscimo para crescimento demográfico), pode-se citar os casos do Jaguaré, Vila Sônia e Sapopemba. Entre os distritos periféricos, cabe destacar a queda das taxas de crescimento nos distritos de Anhanguera, Cidade Tiradentes, Grajaú, Iguatemi, Parelheiros, entre outros.

De qualquer forma, essa aparente "contratendência" deve ser analisada com cuidado em razão das correçóes impostas aos dados da Contagem de 1996, como já explicado. O pequeno aumento corretivo das populaçóes distritais em 1996 conduz a taxas de crescimento demográfico mais elevadas (ou quedas menos acentuadas) entre 1991 e 1996 e aumentos menos significativos (quedas mais expressivas) para o período entre $1996 \mathrm{e}$ 2000 do que se não fossem feitos os ajustes. Assim, para citar um exemplo, pode ser que o ritmo de crescimento demográfico do distrito de Anhanguera, por exemplo, não tenha arrefecido na intensidade apontada entre os dois períodos da década passada, embora provavelmente tenha diminuído. Além disso, deve-se lembrar que os municípios do entorno paulistano continuam crescendo a taxas mais elevadas que a capital, o que continua reforçando a tese da continuidade do processo de crescimento demográfico radiocêntrico. Há, pois, que se buscar novas indicações - ou esperar pela Contagem Populacional de 2005 para apostar no esgotamento do padrão centrífugo de redistribuição espacial da população paulistana e da emergência de uma nova dinâmica - centrípeta e anelar - de recuperação demográfica em direção aos distritos centrais. 
C R E S C I M E N T O U R B A N O, S A L D O S M I G R A T Ó R I O S

Gráfico 2 - Taxa média anual de crescimento demográfico dos distritos - Município de São Paulo, 1980-1991-1996.
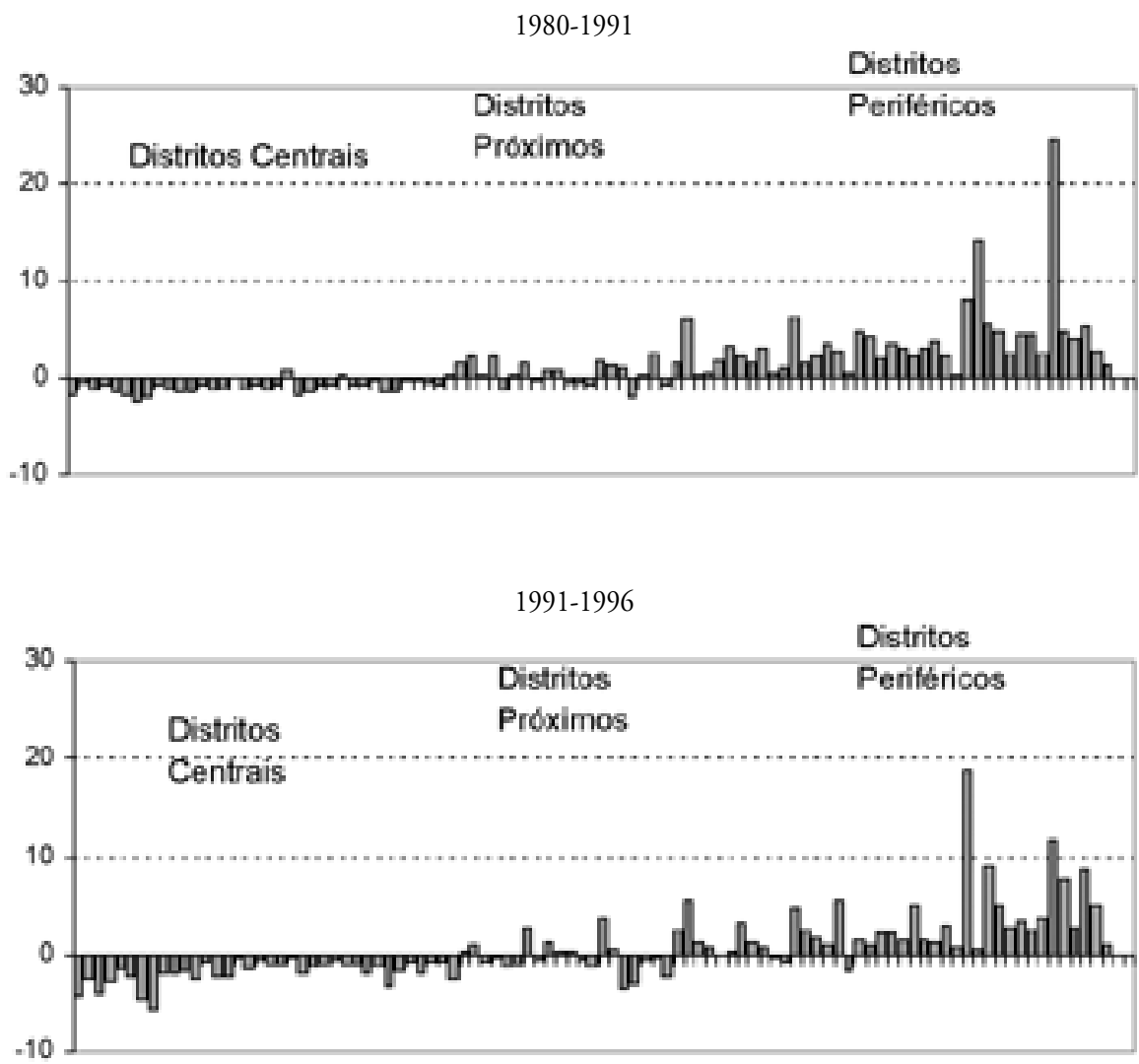

$1996-2000$
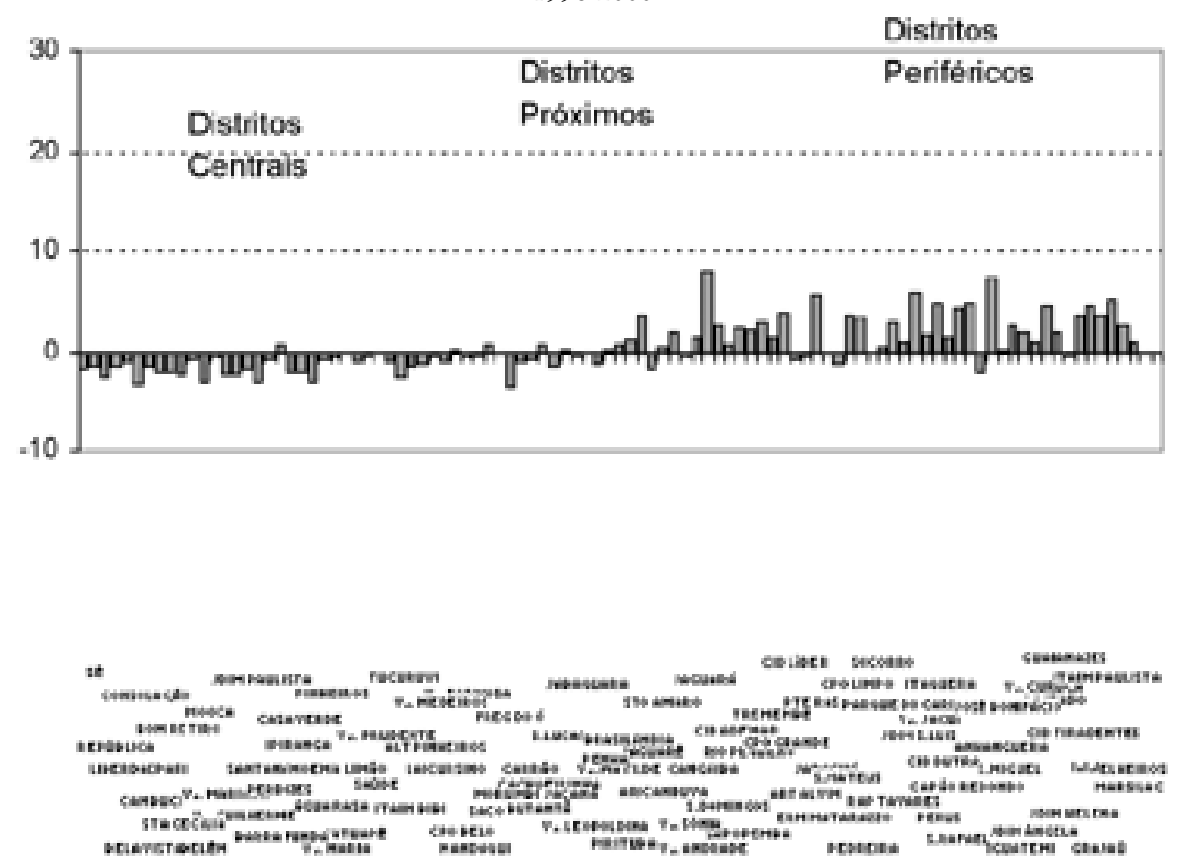


\section{SALDOS MIGRATÓRIOS E ATRATIVIDADE RESIDENCIAL DOS DISTRITOS: 1991-2000}

A publicação dos resultados do Censo Demográfico de 1991 surpreendeu boa parte da comunidade de demógrafos, economistas, urbanistas e outros cientistas sociais pela indicação da forte diminuição do crescimento populacional da capital nos anos 80. Como já se apontou, a taxa de crescimento da população paulistana passou de 3,7\% anuais nos anos 70 para 1,2\% na década seguinte. Segundo Martine (1992), o processo de concentração progressiva da população em grandes centros urbanos começava a mostrar sua exaustão, como decorrência da crise prolongada da década de 1980, da interiorização do desenvolvimento econômico e da fuga às deseconomias da aglomeração urbana. Os fluxos migratórios estariam se redirecionando para cidades médias e a migração de retorno, partindo dos grandes centros, tornou-se mais numerosa (Baeninger, 2000). A capital paulistana estava pois perdendo seu poder de atração/retenção migratória, no bojo da crise do emprego, da perda do dinamismo industrial, da precarização da qualidade de vida. De fato, pela primeira vez em sua história recente, a cidade viria a apresentar um balanço migratório negativo: o saldo migratório estimado para o período de 1980 a 1991 foi de -756 mil pessoas, uma perda líquida de 68 mil pessoas por ano.

O que se presenciou na década de 1990 foi a continuidade da tendência de evasão populacional do município, mas em volumes menores. Pelos cálculos a que se pode chegar com a utilização do modelo demográfico apresentado em Jannuzzi \& Jannuzzi (2000), entre 1991 e 1996 estima-se que, entre entradas e saídas, a evasão tenha sido de pouco menos de 40 mil pessoas por ano ou quase 200 mil nos cinco anos. A população continuou a crescer já que o crescimento vegetativo de uma cidade do porte de São Paulo foi (e continuará sendo por muito tempo) considerável, como revelam os resultados da Tabela 3. Como já se observou, nos anos 90 a cidade veio a crescer a taxas abaixo de $0,9 \%$ ao ano.

Em uma perspectiva espacial, como era de se esperar pelos dados já apresentados, foram os distritos centrais e mais próximos à área central que apresentaram maior evasão populacional, seja por aumento das saídas de residentes ou menor entrada de novos moradores. ${ }^{5}$ Em boa parte desses distritos o crescimento vegetativo foi até suplantado pela evasão migratória, levando a uma diminuição absoluta da população. Houve, pois, o que se poderia conceituar como uma perda da atratividade residencial desses distritos, isto é, a capacidade deles em atrair novos residentes ou fixar os já existentes. De fato, a ampla maioria dos distritos não-periféricos apresentou uma atratividade residencial negativa isto é, uma repulsividade residencial - como se pode notar pelo Gráfico $3{ }^{6}$
5 Para a fluidez do texto emprega-se "evasão" em lugar de "balanço migratório negativo", ainda que esse último termo seja mais preciso.

6 Vide resultados paras os 96 distritos no Apêndice. 
Tabela 3 - Decomposição do crescimento demográfico e outros indicadores segundo grandes áreas - Município de São Paulo, 1991-1996

\begin{tabular}{llllll}
\hline Área & $\begin{array}{l}\text { Crescimento } \\
\text { total }\end{array}$ & $\begin{array}{l}\text { Crescimento } \\
\text { vegetativo }\end{array}$ & $\begin{array}{l}\text { Saldo } \\
\text { migratório }\end{array}$ & $\begin{array}{l}\text { Taxa líquida } \\
\text { de migração } \\
(\mathrm{p} / \text { mil })\end{array}$ & $\begin{array}{l}\text { Coef. Atrat. } \\
\text { residencial } \\
(\mathrm{x} \mathrm{10-7})\end{array}$ \\
\hline Distritos centrais & -65.938 & 21.848 & -87.786 & $-197,0$ & $-4,11$ \\
Distritos próximos & -78.493 & 203.476 & -281.969 & $-70,7$ & $-14,44$ \\
$\quad$ Leste 1 & -51.800 & 76.106 & -127.906 & $-85,1$ & $-7,09$ \\
$\quad$ Norte 1 & 13.625 & 45.581 & -31.956 & $-34,0$ & $-1,87$ \\
$\quad$ Sul 1 & -14.279 & 33.195 & -47.474 & $-74,8$ & $-2,16$ \\
$\quad$ Oeste & -26.040 & 48.593 & -74.633 & $-82,0$ & $-3,31$ \\
Distritos periféricos & 578.559 & 408.250 & 170.309 & 30,4 & 12,84 \\
$\quad$ Leste 2 & 252.869 & 147.214 & 105.655 & 54,6 & 7,42 \\
$\quad$ Norte 2 & 102.054 & 73.028 & 29.027 & 25,5 & 2,18 \\
$\quad$ Sul 2 & 223.635 & 188.008 & 35.628 & 14,0 & 3,24 \\
Total & 434.128 & 633.574 & -199.446 & $-19,9$ & $-5,71$ \\
\hline
\end{tabular}

Nota: Taxa líquida de migração calculada como razão do saldo migratório pela população em 1996.

Seguindo a lógica histórica da ocupação territorial no município, a população de renda mais baixa, que não pode arcar com a valorização fundiária (e do aluguel), acabou se deslocando para moradias mais distantes na periferia ou inchando as favelas já existentes na capital. Os custos de moradia e de vida já figuravam nos anos 80 como um dos determinantes das motivações de mudança de residência dentro da Região Metropolitana, como mostrado em trabalho anterior (Jannuzzi, 2000a). Dados da Pesquisa de Condiçóes de Vida de 1994 e 1998 também corroboram essa assertiva, ao apontar o peso elevado do aluguel na renda familiar das famílias mais pobres residentes na região (Jannuzzi, 2000b). Por fim, como aponta Barbon (2001), com base em dados da Contagem Populacional de 1996 e de pesquisa de campo específica, a maior parte dos residentes das regiōes de ocupação mais recente (e periféricas) já residiam na capital nos anos 80. No distrito de Anhanguera, onde se observou as mais altas taxas de crescimento na década, por exemplo, havia somente 381 chefes não-residentes no município de São Paulo em 1991, de um total de 16 mil novos moradores entre 1991 e 1996. Em Cidade Tiradentes, de um total de 70 mil novos moradores no período, somente 1.438 eram chefes migrantes há menos de 5 anos em São Paulo.

Como já se observou na seção anterior, na segunda metade da década passada a evasão populacional dos distritos centrais e próximos parece ter sido menos intensa, assim como a mobilidade residencial para os distritos periféricos parece ter arrefecido. A magnitude dos saldos migratórios deve ser analisada, contudo, com cautela pelas razóes explicitadas anteriormente. Se, como parece ser pelos resultados aqui apresentados, os diferenciais de atratividade residencial dos distritos estiverem diminuindo - com distritos centrais e mais próximos deixando de ser pontos de forte evasão populacional e Distritos Periféricos perdendo sua atratividade residencial -, isso não invalida a tese do padrão centrífugo de crescimento populacional na metrópole paulista; a escala para análise do fenômeno é que deve ser ampliada, tendo a Região Metropolitana como unidade, tal como realizado por Barbon (2001). 
PA U L O D E A R T I O J A N N UZZ I, N I C O L Á O J A N N UZZ I

Tabela 4 - Decomposição do crescimento demográfico e outros indicadores segundo grandes áreas - Município de São Paulo, 1996-2000

\begin{tabular}{llllll}
\hline Área & $\begin{array}{l}\text { Crescimento } \\
\text { total }\end{array}$ & $\begin{array}{l}\text { Crescimento } \\
\text { vegetativo }\end{array}$ & $\begin{array}{l}\text { Saldo } \\
\text { migratório }\end{array}$ & $\begin{array}{l}\text { Taxa líquida } \\
\text { de migraçáo } \\
(\mathrm{p} / \text { mil })\end{array}$ & $\begin{array}{l}\text { Coef. Atrat. } \\
\text { residencial } \\
(\mathrm{x} \mathrm{10})\end{array}$ \\
\hline Distritos centrais & -33.784 & 16.491 & -50.275 & $-122,1$ & $-2,66$ \\
Distritos próximos & -99.708 & 168.491 & -268.199 & $-69,0$ & $-11,11$ \\
$\quad$ Leste 1 & -14.227 & 62.604 & -76.831 & $-51,6$ & $-3,89$ \\
$\quad$ Norte 1 & 80.072 & 46.633 & 33.439 & 32,8 & $-2,85$ \\
$\quad$ Sul 1 & -7.994 & 24.680 & -32.675 & $-52,1$ & $-2,36$ \\
$\quad$ Oeste & -157.559 & 34.573 & -192.131 & $-255,4$ & $-2,00$ \\
Distritos periféricos & 487.281 & 411.126 & 76.156 & 12,5 & 2,60 \\
$\quad$ Leste 2 & 223.207 & 151.674 & 71.533 & 33,1 & 1,37 \\
$\quad$ Norte 2 & 63.299 & 74.921 & -11.622 & $-9,7$ & $-0,31$ \\
$\quad$ Sul 2 & 200.776 & 184.531 & 16.245 & 5,9 & 1,54 \\
Total & 353.789 & 596.108 & -242.319 & $-23,3$ & $-11,17$ \\
\hline
\end{tabular}

Nota: Taxa líquida de migração calculada como razão do saldo migratório pela população em 2000.

Gráfico 3 - Atratividade urbana residencial dos distritos - Município de São Paulo, 1991-2000.

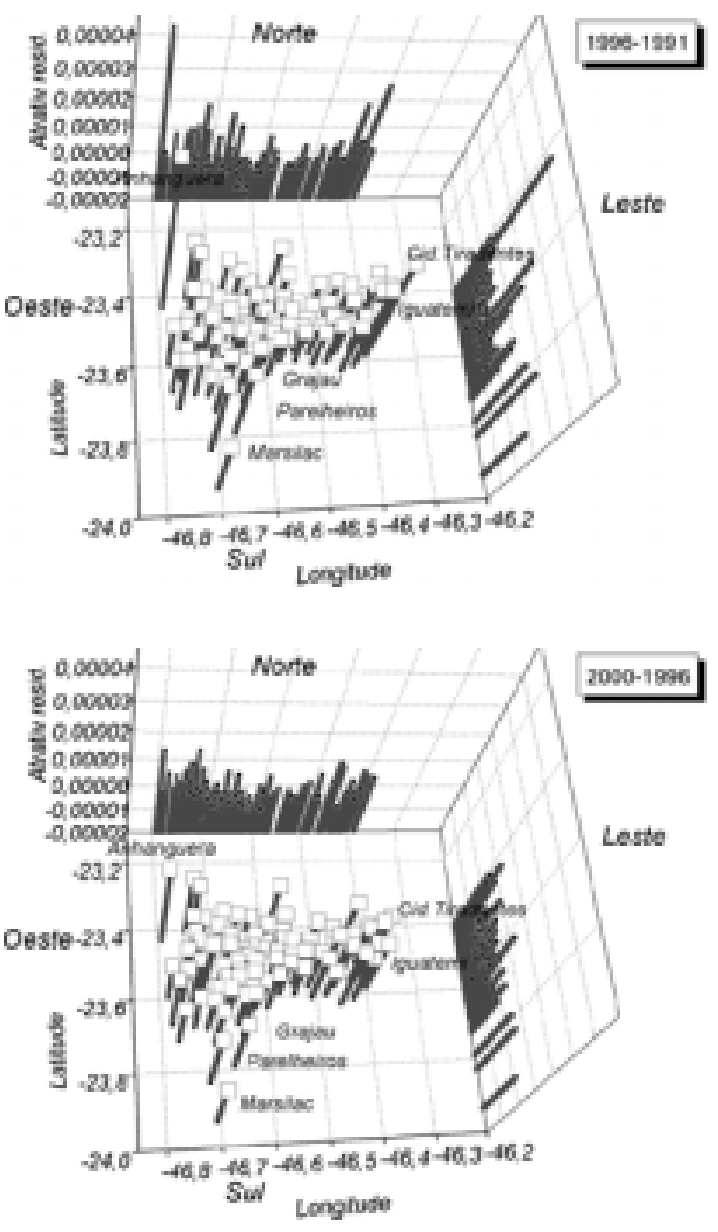




\section{FATORES DETERMINANTES E INTERVENIENTES DA ATRATIVIDADE RESIDENCIAL: UMA CONFRONTAÇÃO EMPÍRICA}

A atratividade urbana residencial de áreas municipais depende de uma série de fatores físico-territoriais, socioespaciais e econômico-urbanos como revelam diversos trabalhos clássicos, revisões bibliográficas e estudos empíricos sobre mobilidade residencial, mobilidade intra-urbana e análises de crescimento urbano (Richardson, 1978; Cepam, 1990; Farret, 1995; Lago, 1998; Smolka, 1998; Faria, 2000; Freitas, 2000; Saboya, 2001).

Em uma concepção clássica, o valor médio da terra urbana seria o fator determinante básico para a atratividade residencial: menor o preço dos terrenos e moradias ou aluguéis maior a propensão da área em receber novos residentes. Naturalmente, diversos outros fatores atuaram subsidiariamente na atratividade residencial das áreas urbanas. Entre os fatores intervenientes da atratividade que podem acentuar ou arrefecer o fenômeno encontram-se a disponibilidade de crédito imobiliário, a existência de serviços urbanos (água, luz, coleta de lixo), a proximidade a equipamentos públicos (escolas, praças etc.), de serviços (comércio, bancos etc.), do local de trabalho, de locais de maior oferta de empregos, deseconomias da aglomeração (violência, qualidade de vida, poluição sonora, do ar e visual), legislação urbanística (uso do solo, avanço do comércio, grau de verticalização permitido etc.), as restriçōes de natureza ambiental ou geográfica (presença de áreas de proteção, áreas sujeitas a inundação etc.), a existência de vazios urbanos, as características do sistema viário, do transporte público, os interesses do capital imobiliário e os impactos decorrentes das intervenções públicas.

Diagrama 1 - Fatores determinantes e intervenientes da atratividade residencial.

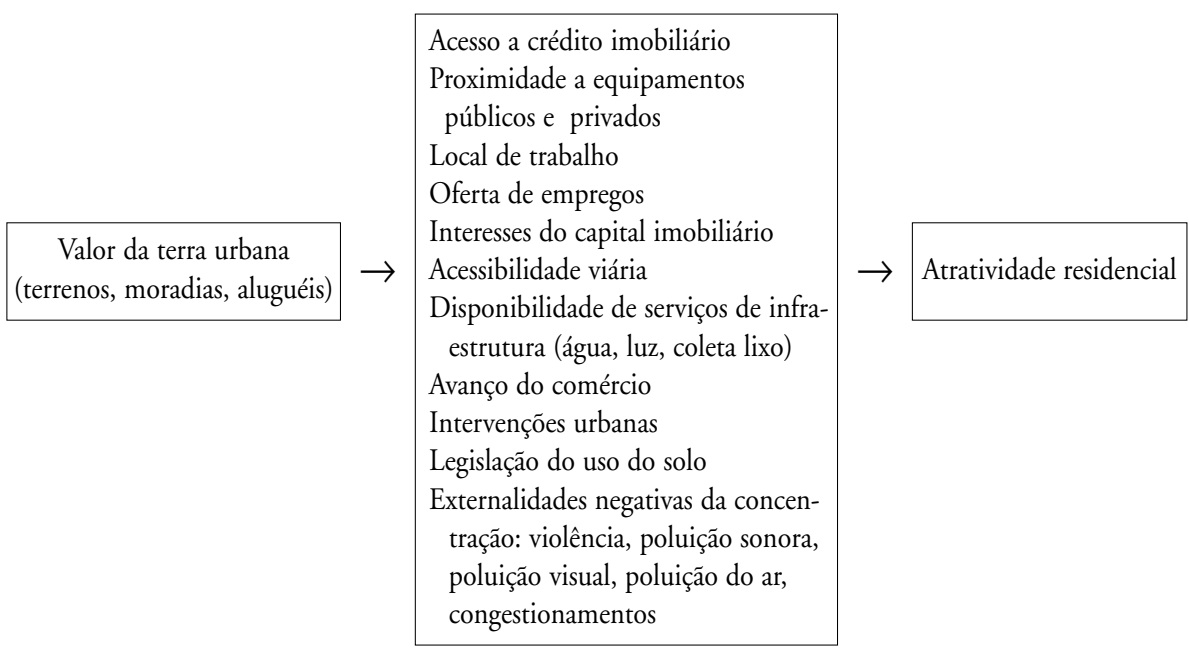

É possível identificar a associação entre alguns desses fatores com a atratividade residencial para os distritos paulistanos com base em alguns indicadores aproximativos (Gráfico 4). Tomando-se, por exemplo, como um indicador do valor médio do terreno nos distritos o Índice de População vivendo com renda do chefe até dois salários mínimos, definido no Mapa da Exclusão/Inclusão Social de Sposati (1996), nota-se que os distritos de maior atratividade residencial são os com nível mais baixo do indicador (menor renda, terrenos mais baratos, maior atratividade). Era de se esperar que tal relação se mos- 
trasse significativa: são as periferias, onde vive a população mais pobre, que mais crescem na capital, isso já há muito tempo. É por essa razão que a relação entre tempo gasto de viagem ao trabalho ou distância ao centro também estão associados com o coeficiente de atratividade residencial (mais periférico, mais longe, mais demorado, custos de moradias mais baixos, maior atratividade).

A antiguidade da ocupação distrital (indicada pela proporção de idosos com 70 anos ou mais), pelo seu significado em termos de avanço do comércio, escritório de serviços e valorização dos aluguéis, repercute negativamente para a atratividade residencial, como era de se esperar (mais antigo, maior avanço do comércio, valorização do aluguel, menor atratividade). De fato, com base nos indicadores urbanísticos dos distritos paulistanos no começo dos anos 90, trazidos por Hermann (2001), pode-se verificar que a atratividade é decrescente com a participação do comércio na área total construída: maior a área ocupada por lojas e outros equipamentos comerciais, menos propenso é o distrito em receber novos moradores.

Assim, acaba não sendo possível à população continuar morando próximo de onde são oferecidos os empregos (daí a relação inversa entre atratividade e taxa de criação de empregos). Morar longe não é uma opção para a maior parte dos residentes da capital, é uma imposição do mercado imobiliário, pela valorização fundiária urbana; e do mercado de trabalho, que não garante rendimentos compatíveis com os custos de moradia e vida na cidade.

Ainda que não surpreendente, vale destacar a relação significativa entre atratividade e adensamento populacional: distritos com maior densidade populacional, medido por habitantes por $\mathrm{km}^{2}$ ou por um índice de verticalização (Hermann, 2001), tendem a atrair cada vez menos residentes pelos efeitos indiretos das deseconomias a ela associadas (congestionamentos, poluição do ar e sonora, avanço do comércio etc.).

Por fim, vale lembrar que as relações empíricas mostradas nos gráficos trazem implícitas a associação inversa entre renda fundiária e atratividade residencial. Mas cada fator selecionado (grau de verticalização, área ocupada pelo comércio etc.) apresenta algum efeito interveniente específico, cuja magnitude pode vir a ser objeto de análise mais aprofundada a partir de bases de dados temporal e metodologicamente mais consistentes, como os que disponibilizados pelo Censo 2000.

Gráfico 4 - Atratividade residencial e variáveis socioespaciais referentes aos distritos Município de São Paulo, 1991-1996.
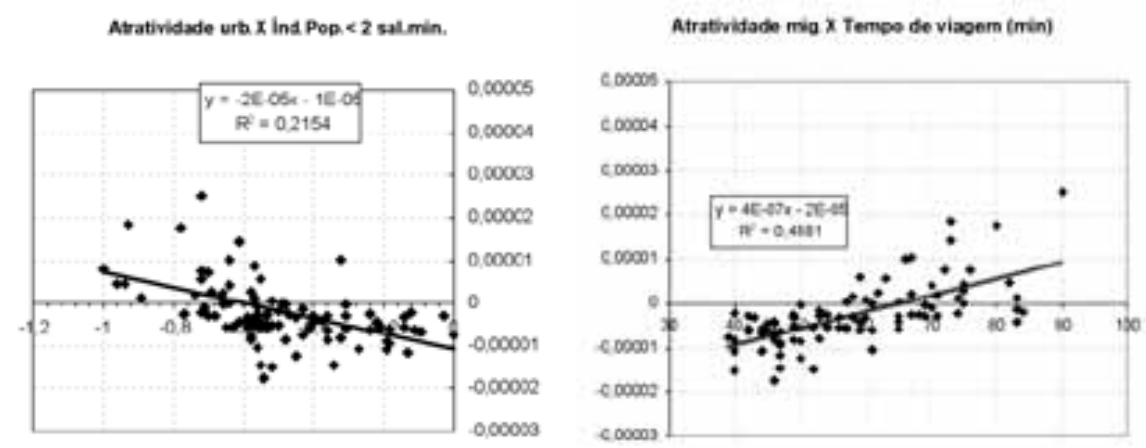

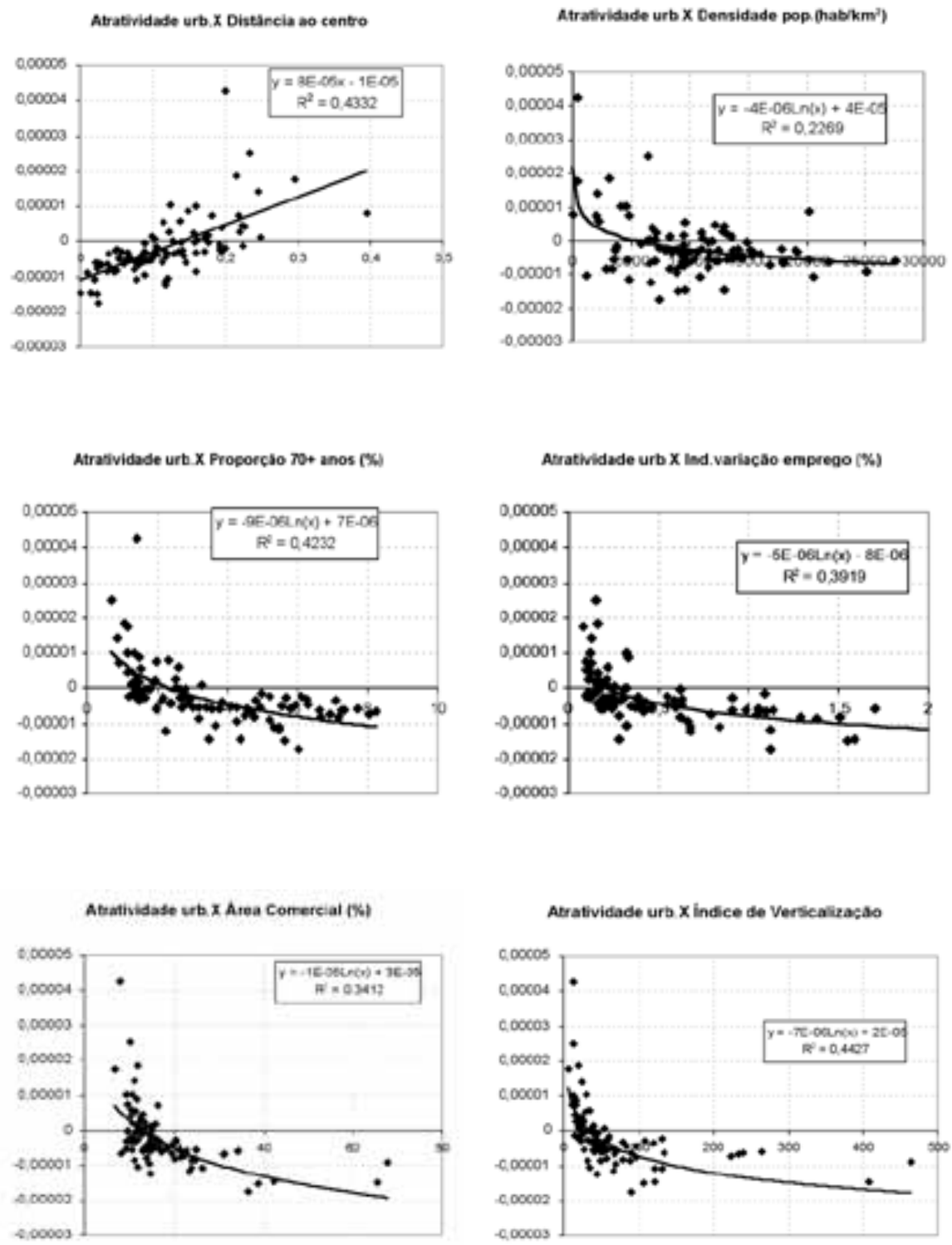

\section{CONSIDERAÇÕES FINAIS}

As evidências empíricas aqui apresentadas mostram a continuidade do processo de mobilidade residencial em direção às áreas mais periféricas do município, seguindo padrão radicocêntrico-centrífugo da ocupação do território paulistano delineado nas primeiras décadas do século XX. Ao longo do período estudado, verificou-se um esvaziamento populacional contínuo de distritos mais centrais e crescimento dos mais periféricos, como resultado da mobilidade de população em busca de terrenos ou aluguéis mais baratos, loteamentos populares ou áreas de invasão, no município e seus arredores. Ao que parece, se deixado à livre ação do mercado, esse processo parece ter uma voracidade implacável.

Rolnik (2000) não poderia resumir de forma mais clara tal realidade: 
Os padrões urbanísticos que se configuram a partir de potente máquina de exclusão territorial definiram uma cidade dualizada, expressa na imagem centro/periferia. Jardim Paulista e Jardim Ângela, Cidade Jardim e Cidade Tiradentes, Higienópolis e Paraisópolis: só quem conhece a cidade consegue entender como nomes tão parecidos podem designar territórios tão diferentes... (p.76.)

Espera-se que os dados aqui apresentados - em especial, o coeficiente de atratividade residencial - possam se revelar úteis para aprofundar o entendimento dessa dualidade histórica do espaço urbano paulistano. Uma possível linha de trabalho seria estudar os efeitos de determinadas intervençôes urbanas, de grandes projetos comerciais (shoppings etc.), da valorização fundiária, da verticalização ou do adensamento sobre a atratividade residencial dos distritos, mediante informaçóes provenientes dos cadastros de imóveis e de obras do município. Isso poderia ajudar a entender melhor os mecanismos da mobilidade intra-urbana, do avanço da periferização pela Região Metropolitana, e também possibilitar a elaboração de projeções populacionais no âmbito distrital com maior grau de segurança.

Enfim, a pertinência de trabalhos dessa natureza cresce, certamente, à medida que se avança na institucionalização do planejamento municipal no País, no bojo da descentralização tributária em favor de Estados e municípios, da transferência de parte das responsabilidades de políticas sociais para as prefeituras (em convênio ou não com outras instâncias de governo) e da previsão constitucional de instrumentos de gestão urbana para municípios com mais de vinte mil habitantes (Plano Diretor). A julgar pelo que colocam Valladares \& Coelho (1996), a preocupação com o melhor embasamento técnico nas atividades relacionadas ao Planejamento Urbano parece estar ganhando terreno no País, depois da desilusão com as distorções induzidas pelas práticas de planejamento tecnocrático dos anos 70. Esse trabalho é uma modesta contribuição neste sentido.

\section{APÊNDICE METODOLÓGICO}

\section{Modelo para EstimaÇão dos Saldos Migratórios e Atratividade Urbana Residencial}

Para decompor o crescimento populacional distrital nas suas duas parcelas constitutivas - crescimento vegetativo, relacionado ao balanço líquido entre nascimentos e óbitos de pessoas, e o saldo migratório, relacionado ao balanço líquido de entradas e saídas de pessoas em cada distrito -, empregou-se um sistema de equaçóes diferenciais usado em ecologia para representar a dinâmica populacional de espécies competitivas dentro de um hábitat fechado, com capacidade de suporte limitada, apresentado anteriormente em Jannuzzi \& Jannuzzi (2000).

Nesse modelo ecológico o crescimento de cada espécie depende de sua taxa de crescimento vegetativo (nascimentos menos óbitos) e da forma de interação com as demais espécies existentes (competição, predação ou parasitismo), forma essa que pode potencializar o ritmo de crescimento ou mesmo a extinção de uma dada espécie (Dajoz, 1983). A adaptação desse modelo para representar a dinâmica populacional de pequenas áreas de uma região é intuitivamente simples, e foi implementado anteriormente por Szwarcwald \& Castilho (1989) para estimar quantitativos populacionais de municípios fluminenses entre 1980 e 1990. Na adaptação do modelo para demonstrar a dinâmica demográfica, as populações das pequenas áreas (no caso, distritos) representam as "espécies", e a região
Paulo de Martino Jannuzzi é professor do Mestrado em Estudos Populacionais e Pesquisa Social da ENCE/BBGE. E-mail: pjannuzzi@ibge.gov.br

Nicoláo Jannuzzi é Especialista Sênior da Fundação Instituto Tecnológico para a Informática.

Artigo recebido para publicação em fevereiro de 2002. 
(município de São Paulo), o hábitat, com seus recursos limitados de espaço físico, imóveis, vias públicas, empregos etc.

Assim, a taxa de crescimento populacional de cada distrito no município dependerá de sua respectiva taxa de crescimento vegetativo - e portanto, em última instância, dos níveis prevalecentes de fecundidade e mortalidade em cada área - e de seu grau de atratividade residencial, proporcionado pelas economias e deseconomias de aglomeração de cada distrito: preços do aluguel; custo dos terrenos e moradias; proximidade de locais de maior oferta de empregos; poluição; custos de transporte; determinantes urbanísticos (uso do solo, grau de verticalização permitido etc.); restrições de natureza ambiental ou geográfica (presença de áreas de proteção, áreas sujeitas a inundação etc.); existência de vazios urbanos; características do sistema viário e do transporte público; e impactos decorrentes das intervenções públicas.

Como representado no sistema de equações diferenciais do Quadro 1, os parâmetros ai dizem respeito à taxa de crescimento vegetativo específico de cada pequena área, enquanto os parâmetros bi referem-se ao grau de atratividade de cada área relativamente às demais (isto é, a competitividade residencial de cada área em relação à população da região). Trata-se, pois, de um modelo que discrimina, para cada área, a contribuição do crescimento vegetativo e do saldo migratório no crescimento populacional.

Como mostrado por Szwarcwald \& Castilho (1989), é possível encontrar uma solução algébrica recursiva para esse sistema de equações diferenciais, desde que se disponha da população municipal em dois momentos, no caso, o Censo Demográfico de 1991 e a Contagem Populacional de 1996.

Quadro 1 - Sistema de equações diferenciais da dinâmica populacional intra-urbana.

$$
\begin{aligned}
& \left(d P_{1} / d t\right)=c_{1} P_{1}(t)+d_{1} P_{1}(t) T(t) \\
& \left(d P_{2} / d t\right)=c_{2} P_{2}(t)+d_{2} P_{2}(t) T(t) \\
& \ldots \ldots . . \\
& \left(d P_{n} / d t\right)=c_{n} P_{n}(t)+d_{n} P_{n}(t) T(t) \\
& \text { sujeito a condição de contorno } \sum_{i=1 . . n} P_{i}(t)=T(t)
\end{aligned}
$$

\footnotetext{
Onde $\mathrm{T}(\mathrm{t})$ : total populacional do município no ano $\mathrm{t}$

$\mathrm{P}_{\mathrm{i}}(\mathrm{t})$ : população do distrito i no ano $\mathrm{t}$

$\mathrm{c}_{\mathrm{i}}$ : taxa de crescimento vegetativo da população do distrito $\mathrm{i}$

$\mathrm{d}_{\mathrm{i}}$ : fator relacionado à atratividade residencial do distrito $\mathrm{i}$
}

A resolução do sistema pode ser realizada da seguinte forma:

$\mathrm{P}_{\mathrm{i}}(\mathrm{t})=\mathrm{P}_{\mathrm{i}}(0)+\Delta \mathrm{P}_{\mathrm{i}}$

$$
\begin{aligned}
& \Delta \mathrm{P}_{\mathrm{i}}=\Delta \mathrm{PF}_{\mathrm{i}}(\mathrm{t}) \mathrm{P}_{\mathrm{i}}(0) / \sum \mathrm{F}_{\mathrm{i}}(\mathrm{t}) \mathrm{P}_{\mathrm{i}}(0) \\
& \operatorname{com} \mathrm{F}_{\mathrm{i}}(\mathrm{t})=\exp \left(\mathrm{a}_{\mathrm{i}}+\mathrm{b}_{\mathrm{i}}\{\ln (\mathrm{T}(\mathrm{t}) / \mathrm{T}(0)\} \mathrm{x}(\mathrm{T}(\mathrm{t})-\mathrm{T}(0)))-1\right.
\end{aligned}
$$

onde $\mathrm{T}(\mathrm{t})$ : total populacional do município

$\mathrm{a}_{\mathrm{i}}: \ln \left(1+\right.$ tx natalidade $_{\mathrm{i}}$ - tx mortalidade $\left.{ }_{\mathrm{i}}\right)$ - taxas médias para o período

estimadas com base na análise das estatísticas vitais

$\mathrm{b}_{\mathrm{i}}$ : grau de atratividade residencial média do distrito ${ }_{\mathrm{i}}$, estimado por

$$
\frac{\mathrm{a}_{\mathrm{i}}+\left\{\ln \left(\mathrm{P}_{\mathrm{i}}(\mathrm{t}) / \mathrm{P}_{\mathrm{i}}(0)\right\}\right.}{\{\ln (\mathrm{T}(\mathrm{t}) / \mathrm{T}(0))\}_{\mathrm{x}}(\mathrm{T}(\mathrm{t})-\mathrm{T}(0))}
$$




\section{APÊNDICE ESTATÍSTICO}

Informações sociodemográficas e parâmetros do modelo em âmbito distrital - Município de São Paulo, 1980-2000.

\begin{tabular}{|c|c|c|c|c|c|c|c|c|c|c|c|c|c|c|c|c|c|c|c|c|}
\hline \multirow[t]{2}{*}{ Distritos } & \multirow[t]{2}{*}{ Zona } & \multicolumn{4}{|c|}{ População Total } & \multirow{2}{*}{$\begin{array}{l}\text { Taxa } \\
\text { cresc. } \\
80-91\end{array}$} & \multirow{2}{*}{$\begin{array}{l}\text { Média } \\
\text { Demog. } \\
91-96\end{array}$} & \multirow{2}{*}{$\begin{array}{l}\text { Anual } \\
(\%)\end{array}$} & \multirow{2}{*}{$\begin{array}{l}\text { Saldo } \\
91-96\end{array}$} & \multirow{2}{*}{$\begin{array}{l}\text { Migrat. } \\
96-00\end{array}$} & \multirow{2}{*}{$\begin{array}{l}\mathrm{Ai} \\
\times 100 \\
91-96\end{array}$} & \multirow{2}{*}{$\begin{array}{l}\mathrm{Bi} \\
\times 1 \mathrm{E}-6\end{array}$} & \multirow{2}{*}{$\begin{array}{l}\text { Ai } \\
x 100\end{array}$} & \multirow{2}{*}{$\begin{array}{l}\mathrm{Bi} \\
\times 1 \mathrm{E}-6\end{array}$} & \multirow{2}{*}{$\begin{array}{l}\text { Ind. } \\
\text { Qual. } \\
\text { Vida } \\
1991\end{array}$} & \multirow{2}{*}{$\begin{array}{l}\text { Prop. } \\
\text { pop. cl } \\
70+ \\
1991\end{array}$} & \multirow{2}{*}{$\begin{array}{l}\text { Ind. } \\
\text { pop. até } \\
2 \text { mí- } \\
\text { nimos } \\
1991\end{array}$} & \multirow{2}{*}{ 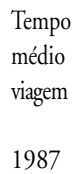 } & \multirow{2}{*}{$\begin{array}{l}\text { Densid. } \\
\text { hab/km² }\end{array}$} & \multirow{2}{*}{$\begin{array}{l}\text { Ind. } \\
\text { varia- } \\
\text { ção em- } \\
\text { prego } \\
90-94\end{array}$} \\
\hline & & 1980 & 1991 & 1996 & 2000 & & & & & & & & & & & & & & & \\
\hline Água Rasa & E1 & 112.007 & 94.749 & 88.481 & 85.764 & $-1,51$ & $-1,36$ & $-0,78$ & -8978 & -4985 & 2,8 & $-5,0$ & 3,2 & $-3,3$ & 0,11 & 5,55 & $-0,52$ & 54 & 13731,74 & $\overline{0,35}$ \\
\hline Alto de Pinheiros & W & 50.941 & 50.164 & 45.249 & 44.386 & $-0,14$ & $-2,04$ & $-0,48$ & -6069 & -1534 & 2,3 & $-6,6$ & 1,8 & $-2,0$ & 0,61 & 4,7 & $-0,1$ & 46 & 6514,805 & 0,42 \\
\hline Anhanguera & $\mathrm{N} 2$ & 5.323 & 12.362 & 29.128 & 38.475 & 7,96 & 18,70 & 7,21 & 16260 & 7692 & 4,0 & 42,6 & 6,9 & 13,2 & 0,28 & 1,43 & $-0,64$ & & 371,2312 & 0 \\
\hline Aricanduva & E1 & 92.832 & 96.156 & 93.347 & 94.692 & 0,32 & $-0,59$ & 0,36 & -7985 & -2885 & 5,2 & $-4,3$ & 5,5 & $-1,7$ & $-0,08$ & 2,42 & $-0,61$ & 65 & 14569,09 & 0,26 \\
\hline Artur Alvim & E1 & 106.658 & 118.095 & 112.790 & 110.711 & 0,93 & $-0,92$ & $-0,46$ & -13373 & -8420 & 6,6 & $-5,8$ & 6,8 & $-4,3$ & 0,20 & 1,95 & $-0,53$ & 65 & 17893,18 & 0,18 \\
\hline Barra Funda & W & 17.818 & 15.918 & 14.638 & 12.927 & $-1,02$ & $-1,66$ & $-3,06$ & -2518 & -2189 & 7,5 & $-8,3$ & 4,0 & $-9,2$ & 0,55 & 6,65 & $-0,32$ & 40 & 2842,5 & 1,29 \\
\hline Bela Vista & $\mathrm{C}$ & 84.973 & 71.560 & 66.252 & 63.099 & $-1,55$ & $-1,53$ & $-1,21$ & -7876 & -5096 & 3,5 & $-5,9$ & 3,6 & $-4,5$ & 0,39 & 5,78 & $-0,18$ & 42 & 27523,08 & 1,7 \\
\hline Belém & E1 & 58.077 & 49.514 & 43.473 & 38.241 & $-1,44$ & $-2,57$ & $-3,15$ & -7612 & -6857 & 3,1 & $-8,4$ & 4,6 & $-9,7$ & 0,21 & 7,16 & $-0,58$ & 46 & 8252,333 & 1,51 \\
\hline Bom Retiro & C & 47.350 & 36.004 & 28.368 & 26.550 & $-2,46$ & $-4,66$ & $-1,64$ & -9506 & -3304 & 5,1 & $-15,1$ & 6,3 & $-6,9$ & 0,31 & 5,63 & $-0,52$ & 40 & 9001 & 1,55 \\
\hline Brás & C & 38.455 & 33.413 & 27.221 & 24.488 & $-1,27$ & $-4,02$ & $-2,61$ & -8774 & -4735 & 7,4 & $-14,6$ & 8,8 & $-10,3$ & $-0,20$ & 4,37 & $-0,55$ & 47 & 9546,571 & 1,59 \\
\hline Brasilândia & N2 & 165.590 & 200.849 & 240.234 & 246.759 & 1,77 & 3,65 & 0,67 & 24726 & -11578 & 7,0 & 5,7 & 9,0 & $-2,6$ & $-0,27$ & 1,55 & $-0,72$ & 63 & 9564,238 & 0,11 \\
\hline Butantã & W & 56.670 & 57.804 & 54.638 & 52.495 & 0,18 & $-1,12$ & $-1,00$ & -6062 & -4200 & 4,9 & $-5,5$ & 4,6 & $-4,5$ & 0,63 & 4,27 & $-0,21$ & 56 & 4624,32 & 0,6 \\
\hline Cachoeirinha & $\mathrm{N} 2$ & 105.182 & 125.389 & 143.806 & 147.446 & 1,61 & 2,78 & 0,63 & 4043 & -9497 & 10,9 & 1,5 & 10,8 & $-3,6$ & 0,26 & 1,9 & $-0,67$ & 58 & 9427,744 & 0,15 \\
\hline Cambuci & C & 44.646 & 36.932 & 32.760 & 28.600 & $-1,71$ & $-2,37$ & $-3,34$ & -5116 & -5118 & 2,5 & $-7,6$ & 3,6 & $-9,7$ & 0,51 & 6,92 & $-0,43$ & 39 & 9469,744 & 0,79 \\
\hline Campo Belo & S2 & 75.311 & 77.666 & 67.943 & 66.268 & 0,28 & $-2,64$ & $-0,62$ & -13461 & -3509 & 4,7 & $-9,4$ & 3,3 & $-3,0$ & 0,60 & 4,25 & $-0,18$ & 47 & 8825,682 & 0,66 \\
\hline Campo Grande & S2 & 70.154 & 81.750 & 86.621 & 91.142 & 1,40 & 1,16 & 1,28 & -378 & 635 & 6,2 & $-0,2$ & 5,5 & 0,5 & 0,13 & 2,79 & $-0,31$ & 61 & 6240,458 & 0,62 \\
\hline Campo Limpo & S2 & 109.987 & 158.885 & 165.482 & 190.706 & 3,40 & 0,82 & 3,61 & -9761 & 10908 & 9,8 & $-3,0$ & 10,3 & 3,6 & $-0,21$ & 1,44 & $-0,53$ & 69 & 12412,89 & 0,24 \\
\hline Cangaíba & N1 & 97.323 & 114.646 & 129.097 & 135.993 & 1,50 & 2,40 & 1,31 & 6051 & -785 & 7,1 & 2,5 & 7,2 & $-0,3$ & $-0,08$ & 2,53 & $-0,58$ & 62 & 7165,375 & 0,21 \\
\hline Capão Redondo & S2 & 127.634 & 192.785 & 204.504 & 242.198 & 3,82 & 1,19 & 4,32 & -8947 & 17508 & 10,2 & $-2,2$ & 11,6 & 4,5 & 0,29 & 1,2 & $-0,72$ & 74 & 14175,37 & 0,1 \\
\hline Carrão & E1 & 98.706 & 87.014 & 81.082 & 77.507 & $-1,14$ & $-1,40$ & $-1,12$ & -8786 & -5805 & 3,2 & $-5,4$ & 3,4 & $-4,2$ & 0,00 & 4,92 & $-0,57$ & 54 & 11601,87 & 0,37 \\
\hline Casa Verde & $\mathrm{N} 2$ & 103.751 & 96.040 & 90.793 & 83.556 & $-0,70$ & $-1,12$ & $-2,06$ & -9468 & -10794 & 4,3 & $-5,2$ & 4,8 & $-7,1$ & 0,11 & 4,09 & $-0,5$ & 49 & 13526,76 & 0,4 \\
\hline Cidade Ademar & S2 & 218.616 & 229.945 & 238.463 & 243.103 & 0,46 & 0,73 & 0,48 & -15738 & -14674 & 10,0 & $-3,3$ & 9,6 & $-3,4$ & $-0,33$ & 1,51 & $-0,59$ & 60 & 19162,08 & 0,19 \\
\hline Cidade Dutra & S2 & 122.418 & 168.199 & 179.940 & 189.946 & 2,93 & 1,36 & 1,36 & -3137 & -3488 & 8,5 & $-0,9$ & 9,0 & $-1,0$ & 0,21 & 1,54 & $-0,56$ & 70 & 5740,58 & 0,15 \\
\hline Cidade Líder & E2 & 70.156 & 97.012 & 100.364 & 116.089 & 2,99 & 0,68 & 3,71 & -5128 & 8354 & 8,4 & $-2,6$ & 8,8 & 4,5 & 0,14 & 1,66 & $-0,53$ & 67 & 9510,98 & 0,19 \\
\hline
\end{tabular}




\begin{tabular}{|c|c|c|c|c|c|c|c|c|c|c|}
\hline \multirow[t]{2}{*}{ Distritos } & \multirow[t]{2}{*}{ Zona } & & \multicolumn{3}{|c|}{ População Total } & \multirow{2}{*}{$\begin{array}{l}\text { Taxa } \\
\text { cresc. } \\
80-91\end{array}$} & \multirow{2}{*}{$\begin{array}{l}\text { Média } \\
\text { Demog. } \\
91-96\end{array}$} & \multirow{2}{*}{ 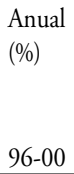 } & \multirow{2}{*}{$\begin{array}{l}\text { Saldo } \\
91-96\end{array}$} & \multirow{2}{*}{$\begin{array}{l}\text { Migrat. } \\
96-00\end{array}$} \\
\hline & & 1980 & 1991 & 1996 & 2000 & & & & & \\
\hline Cidade Tiradentes & E2 & 8.566 & 95.926 & 166.046 & 190.421 & 24,56 & 11,60 & 3,48 & 63490 & 11775 \\
\hline Consolação & C & 76.953 & 66.343 & 59.815 & 54.263 & $-1,34$ & $-2,05$ & $-2,41$ & -8292 & -6471 \\
\hline Cursino & S1 & 115.876 & 110.028 & 106.261 & 101.858 & $-0,47$ & $-0,69$ & $-1,05$ & -8523 & -8434 \\
\hline E. Matarazzo & E2 & 80.166 & 95.257 & 107.396 & 106.656 & 1,58 & 2,43 & $-0,17$ & 4524 & -8604 \\
\hline Freguesia do Ó & N2 & 149.946 & 152.110 & 145.310 & 144.367 & 0,13 & $-0,91$ & $-0,16$ & -15559 & -8457 \\
\hline Grajaú & S2 & 116.717 & 193.042 & 278.362 & 331.738 & 4,68 & 7,59 & 4,48 & 66274 & 26519 \\
\hline Guaianazes & E2 & 50.167 & 81.074 & 90.860 & 98.068 & 4,46 & 2,31 & 1,93 & -2188 & -1557 \\
\hline Iguatemi & E2 & 33.002 & 59.600 & 91.707 & 101.617 & 5,52 & 9,00 & 2,60 & 27402 & 2784 \\
\hline Ipiranga & S2 & 117.075 & 101.158 & 95.962 & 98.166 & $-1,32$ & $-1,05$ & 0,57 & -8622 & -783 \\
\hline Itaim Bibi & S2 & 127.886 & 107.099 & 90.418 & 81.274 & $-1,60$ & $-3,33$ & $-2,63$ & -20897 & -11326 \\
\hline Itaim Paulista & E2 & 106.787 & 162.669 & 184.533 & 212.528 & 3,90 & 2,55 & 3,59 & 4024 & 11046 \\
\hline Itaquera & E2 & 127.300 & 174.720 & 188.392 & 201.037 & 2,92 & 1,52 & 1,64 & -445 & -192 \\
\hline Jabaquara & S1 & 195.416 & 213.559 & 216.889 & 214.049 & 0,81 & 0,31 & $-0,33$ & -11152 & -15992 \\
\hline Jaçanã & N1 & 79.682 & 86.511 & 91.517 & 91.585 & 0,75 & 1,13 & 0,02 & 1341 & -4389 \\
\hline Jaguará & W & 32.609 & 29.688 & 26.266 & 25.683 & $-0,85$ & $-2,42$ & $-0,56$ & -5840 & -1597 \\
\hline Jaguaré & W & 39.701 & 44.199 & 36.857 & 42.380 & 0,98 & $-3,57$ & 3,55 & -9812 & 3124 \\
\hline Jaraguá & $\mathrm{N} 2$ & 47.213 & 92.841 & 116.759 & 145.423 & 6,34 & 4,69 & 5,64 & 17979 & 19689 \\
\hline Jardim Ângela & S2 & 107.113 & 177.717 & 226.041 & 243.674 & 4,71 & 4,93 & 1,90 & 29678 & -5104 \\
\hline Jardim Helena & E2 & 90.663 & 117.945 & 140.472 & 138.488 & 2,42 & 3,56 & $-0,35$ & 11352 & -13145 \\
\hline Jardim Paulista & S2 & 116.561 & 102.754 & 91.131 & 82.599 & $-1,14$ & $-2,37$ & $-2,43$ & -13706 & -9465 \\
\hline Jardim São Luís & S2 & 162.808 & 203.533 & 227.908 & 236.801 & 2,05 & 2,29 & 0,96 & 4448 & -10473 \\
\hline José Bonifácio & E2 & 23.936 & 103.330 & 106.102 & 106.978 & 14,22 & 0,53 & 0,21 & -4057 & -5220 \\
\hline Lajeado & E2 & 69.107 & 112.392 & 132.434 & 157.724 & 4,52 & 3,34 & 4,47 & 11206 & 13565 \\
\hline Lapa & W & 83.284 & 70.059 & 64.276 & 60.028 & $-1,56$ & $-1,71$ & $-1,69$ & -7586 & -5141 \\
\hline Liberdade & C & 82.062 & 75.963 & 65.695 & 61.807 & $-0,70$ & $-2,86$ & $-1,51$ & -15243 & -6795 \\
\hline Limão & N2 & 88.515 & 90.089 & 85.748 & 81.959 & 0,16 & $-0,98$ & $-1,12$ & -9252 & -7854 \\
\hline Mandaqui & N1 & 87.789 & 103.639 & 104.092 & 102.989 & 1,52 & 0,09 & $-0,27$ & -5780 & -5668 \\
\hline Marsilac & S2 & 4.420 & 5.970 & 7.570 & 8.410 & 2,77 & 4,86 & 2,67 & 1069 & 229 \\
\hline
\end{tabular}

$\begin{array}{llll}\mathrm{Ai} & \mathrm{Bi} & \mathrm{Ai} & \mathrm{Bi} \\ \text { x100 } & \text { x1E-6 } & \text { x100 } & \text { x1E-6 }\end{array}$

Ind.
Qual.
Vida

Prop. In

Tempo Densid. Ind. p.cl pop. até médio hab $/ \mathrm{km}^{2}$ varia-

6,7
2,6
4,2
7,7
5,6
9,4
13,8
7,6
3,
3,
10,4
7,8
6,6
4,1
7,8
5,4
6,2
10,0
9,
2,0
9,3
6,4
7,6
2,5
6,3
5,3
5,8
8,5

$\begin{array}{lll}25,1 & 9,1 & 3,8 \\ -6,8 & 1,9 & -6,6 \\ -4,0 & 4,6 & -4,6 \\ 2,2 & 8,8 & -4,5 \\ -5,3 & 6,3 & -3,3 \\ 14,2 & 11,4 & 5,0 \\ -1,2 & 11,4 & -0,8 \\ 18,5 & 9,3 & 1,7 \\ -4,5 & 3,8 & -0,4 \\ -10,8 & 3,0 & -7,6 \\ 1,1 & 10,9 & 3,2 \\ -0,1 & 8,2 & 0,0 \\ -2,6 & 7,3 & -4,2 \\ 0,8 & 5,9 & -2,7 \\ -10,5 & 4,7 & -3,5 \\ -12,3 & 7,8 & 4,6 \\ 8,7 & 9,2 & 8,7 \\ 7,3 & 11,8 & -1,1 \\ 4,4 & 9,5 & -5,3 \\ -7,3 & 1,3 & -6,4 \\ 1,0 & 10,1 & -2,5 \\ -2,0 & 6,9 & -2,7 \\ 4,6 & 10,5 & 5,4 \\ -5,8 & 1,7 & -4,8 \\ -10,9 & 5,4 & -6,1 \\ -5,3 & 5,8 & -5,3 \\ -2,8 & 5,3 & -3,1 \\ 7,9 & 9,6 & 1,7 \\ & & \end{array}$

$\begin{array}{llllll}0,25 & 0,71 & -0,72 & 90 & 6395,067 & 0,15 \\ 0,42 & 8,22 & -0,09 & 44 & 17930,54 & 1,1 \\ 0,40 & 3,86 & -0,38 & 46 & 9169 & 0,43 \\ -0,20 & 1,94 & -0,66 & 67 & 10949,08 & 0,17 \\ 0,05 & 3,04 & -0,57 & 56 & 14486,67 & 0,25 \\ -0,36 & 0,85 & -0,61 & 73 & 2098,283 & 0,13 \\ -0,52 & 1,33 & -0,71 & 83 & 9427,209 & 0,11 \\ -0,49 & 1,07 & -0,93 & 73 & 3040,816 & 0,16 \\ 0,41 & 6,29 & -0,4 & 46 & 9634,095 & 0,63 \\ 0,69 & 5,33 & -0,19 & 44 & 10818,08 & 0,84 \\ -0,43 & 1,25 & -0,89 & 83 & 13555,75 & 0,16 \\ -0,30 & 1,79 & -0,64 & 75 & 11967,12 & 0,16 \\ -0,10 & 2,73 & -0,47 & 54 & 15146,03 & 0,31 \\ 0,15 & 3,28 & -0,57 & 60 & 11091,15 & 0,21 \\ -0,06 & 3,68 & -0,56 & 61 & 1075,652 & 0,32 \\ 0,03 & 2,26 & -0,45 & 50 & 6696,818 & 0,68 \\ 0,07 & 1,48 & -0,57 & & 20182,83 & 0,33 \\ -0,47 & 0,91 & -0,7 & 76 & 4751,791 & 0,13 \\ -0,62 & 1,3 & -0,94 & 75 & 12960,99 & 0,16 \\ 0,45 & 8,04 & 0 & 46 & 16844,92 & 1,05 \\ -0,33 & 1,25 & -0,57 & 74 & 8240,202 & 0,16 \\ 0,27 & 1,31 & -0,5 & 84 & 7328,369 & 0,1 \\ -0,75 & 1,14 & -0,96 & 82 & 12216,52 & 0,12 \\ 0,70 & 7,7 & -0,31 & 44 & 7005,9 & 1,06 \\ 0,12 & 5,47 & -0,27 & 40 & 20530,54 & 0,68 \\ -0,04 & 3,17 & -0,53 & 54 & 14299,84 & 0,4 \\ -0,05 & 2,86 & -0,4 & 53 & 7911,374 & 0,22 \\ -1,00 & 2,32 & -1 & & 29,85 & 0\end{array}$


Ai B Ai

Bi

Ind.

Prop. Ind. Tempo Densid. Ind.

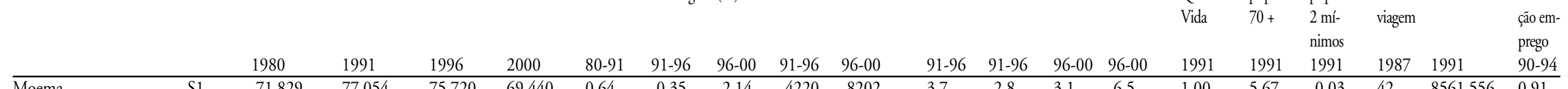

Moema

Mooca
Morumbi

Parelheiros

Pari

Parque do Carmo

Pedreira

Penha

Perdizes

Perdizes
Perus

Pinheiros

Pirituba

Ponte Rasa

Raposo Tavares

República

Rio Pequeno

Sacomã

Santa Cecília

Santana

Santo Amaro

São Domingos

São Lucas

São Mateus

São Miguel

São Rafael

Sapopemba

Saúde

$\begin{array}{lllllllll}71.829 & 77.054 & 75.720 & 69.440 & 0,64 & -0,35 & -2,14 & -4220 & -8202 \\ 84.232 & 71.733 & 65.179 & 63.167 & -1,45 & -1,90 & -0,78 & -8232 & -3098 \\ 30.923 & 39.884 & 39.356 & 33.867 & 2,34 & -0,27 & -3,69 & -4322 & -9097 \\ 31.548 & 55.390 & 84.255 & 102.421 & 5,25 & 8,75 & 5,00 & 24265 & 10142 \\ 26.830 & 21.221 & 15.756 & 14.511 & -2,11 & -5,78 & -2,04 & -6286 & -1937 \\ 34.945 & 54.542 & 57.325 & 63.878 & 4,13 & 1,00 & 2,74 & -3192 & 1472 \\ 62.764 & 85.685 & 111.617 & 127.389 & 2,87 & 5,43 & 3,36 & 19541 & 8634 \\ 139.558 & 132.515 & 129.611 & 123.080 & -0,47 & -0,44 & -1,28 & -8444 & -10950 \\ 116.885 & 108.438 & 105.915 & 102.088 & -0,68 & -0,47 & -0,92 & -4631 & -5125 \\ 36.037 & 46.131 & 58.802 & 70.665 & 2,27 & 4,97 & 4,70 & 7843 & 6463 \\ 94.189 & 78.352 & 70.998 & 62.349 & -1,66 & -1,95 & -3,20 & -9261 & -9815 \\ 132.070 & 151.743 & 154.713 & 161.619 & 1,27 & 0,39 & 1,10 & -7776 & -1747 \\ 96.329 & 102.324 & 100.546 & 97.516 & 0,55 & -0,35 & -0,76 & -8234 & -8116 \\ 49.153 & 82.586 & 89.028 & 90.517 & 4,83 & 1,51 & 0,42 & 530 & -5616 \\ 60.713 & 57.585 & 50.702 & 47.426 & -0,48 & -2,51 & -1,66 & -9510 & -5207 \\ 84.435 & 102.414 & 101.501 & 111.613 & 1,77 & -0,18 & 2,40 & -6668 & 1941 \\ 163.146 & 210.423 & 221.394 & 227.264 & 2,34 & 1,02 & 0,66 & -1889 & -6364 \\ 94.134 & 85.511 & 77.412 & 71.061 & -0,87 & -1,97 & -2,12 & -10091 & -8299 \\ 138.379 & 137.172 & 134.767 & 124.948 & -0,08 & -0,35 & -1,87 & -6461 & -12839 \\ 92.855 & 75.278 & 64.304 & 59.716 & -1,89 & -3,10 & -1,83 & -16003 & -6065 \\ 69.129 & 70.127 & 74.440 & 82.766 & 0,13 & 1,20 & 2,69 & 232 & 4462 \\ 155.699 & 151.476 & 147.654 & 138.989 & -0,25 & -0,51 & -1,50 & -12661 & -14269 \\ 118.228 & 150.209 & 163.452 & 154.677 & 2,20 & 1,70 & -1,37 & -1072 & -19732 \\ 100.904 & 102.585 & 105.818 & 97.258 & 0,15 & 0,62 & -2,09 & -5481 & -15860 \\ 70.092 & 89.533 & 103.647 & 125.044 & 2,25 & 2,97 & 4,80 & 7729 & 14730 \\ 181.309 & 256.671 & 260.239 & 281.787 & 3,21 & 0,28 & 2,01 & -14480 & 5055 \\ 135.653 & 126.128 & 120.255 & 117.827 & -0,66 & -0,95 & -0,51 & -10796 & -6148 \\ 32.817 & 27.086 & 21.699 & 20.092 & -1,73 & -4,34 & -1,91 & -7092 & -3313\end{array}$

$\begin{array}{llllllllll}3,7 & -2,8 & 3,1 & -6,5 & 1,00 & 5,67 & -0,03 & 42 & 8561,556 & 0,91 \\ 2,3 & -6,2 & 2,1 & -2,8 & 0,58 & 7,33 & -0,36 & 45 & 9315,974 & 0,98 \\ 9,1 & -5,4 & 10,9 & -13,9 & 0,74 & 2,67 & -0,14 & 57 & 3498,596 & 0,46 \\ 8,0 & 17,7 & 11,2 & 6,2 & -0,56 & 1,13 & -0,78 & 80 & 360,8469 & 0,08 \\ 3,8 & -17,5 & 5,3 & -7,3 & -0,02 & 6,02 & -0,54 & 46 & 7317,586 & 1,12 \\ 10,4 & -2,8 & 10,5 & 1,5 & -0,37 & 1,4 & -0,7 & 65 & 3541,688 & 0,19 \\ 7,2 & 10,0 & 7,7 & 4,2 & -0,37 & 1,32 & -0,64 & 66 & 4582,086 & 0,12 \\ 4,1 & -3,3 & 4,2 & -5,0 & -0,02 & 4,8 & -0,57 & 56 & 11726,99 & 0,29 \\ 1,9 & -2,2 & 1,5 & -2,8 & 0,78 & 6,11 & -0,12 & 40 & 17776,72 & 0,55 \\ 10,0 & 7,5 & 10,9 & 5,7 & -0,46 & 1,96 & -0,72 & 72 & 1930,167 & 0,1 \\ 2,4 & -6,4 & 2,0 & -8,6 & 0,40 & 7,23 & -0,11 & 47 & 9794 & 1,14 \\ 6,8 & -2,6 & 6,8 & -0,6 & 0,05 & 2,64 & -0,56 & 54 & 8873,86 & 0,25 \\ 6,1 & -4,1 & 6,1 & -4,7 & -0,08 & 2,37 & -0,59 & 83 & 15988,13 & 0,2 \\ 6,9 & 0,3 & 9,5 & -3,5 & 0,23 & 1,43 & -0,52 & 65 & 6554,444 & 0,26 \\ 4,5 & -9,0 & 4,7 & -6,1 & 0,00 & 5,18 & -0,19 & 47 & 25036,96 & 5,16 \\ 5,5 & -3,3 & 9,6 & 1,1 & -0,09 & 2,11 & -0,45 & 56 & 10558,14 & 0,24 \\ 5,9 & -0,4 & 6,7 & -1,6 & 0,00 & 2,64 & -0,48 & 50 & 14818,52 & 0,31 \\ 2,3 & -6,4 & 3,1 & -6,5 & 0,26 & 6,62 & -0,24 & 42 & 21925,9 & 0,91 \\ 2,9 & -2,4 & 2,8 & -5,7 & 0,45 & 5,2 & -0,24 & 49 & 10886,67 & 0,39 \\ 6,5 & -11,6 & 2,8 & -5,7 & 0,66 & 5,48 & -0,13 & 47 & 4825,513 & 1,12 \\ 5,7 & 0,2 & 6,3 & 3,3 & -0,10 & 2,52 & -0,49 & 57 & 7012,7 & 0,32 \\ 5,7 & -4,3 & 4,6 & -5,7 & -0,08 & 2,86 & -0,55 & 59 & 15300,61 & 0,16 \\ 9,1 & -0,3 & 8,0 & -7,0 & 0,26 & 1,65 & -0,66 & 69 & 11554,54 & 0,17 \\ 8,2 & -2,6 & 8,3 & -8,8 & -0,35 & 2,17 & -0,77 & 68 & 13678 & 0,23 \\ 6,9 & 4,0 & 7,7 & 7,5 & 0,18 & 1,33 & -0,64 & 70 & 6782,803 & 0,16 \\ 6,8 & -2,8 & 7,6 & 1,1 & -0,21 & 1,53 & -0,68 & 71 & 19012,67 & 0,12 \\ 3,8 & -4,5 & 3,8 & -2,9 & 0,53 & 5,95 & -0,22 & 45 & 14171,69 & 0,55 \\ 6,1 & -14,7 & 9,4 & -8,9 & -0,31 & 3,47 & -0,34 & 52 & 12898,1 & 0,28\end{array}$




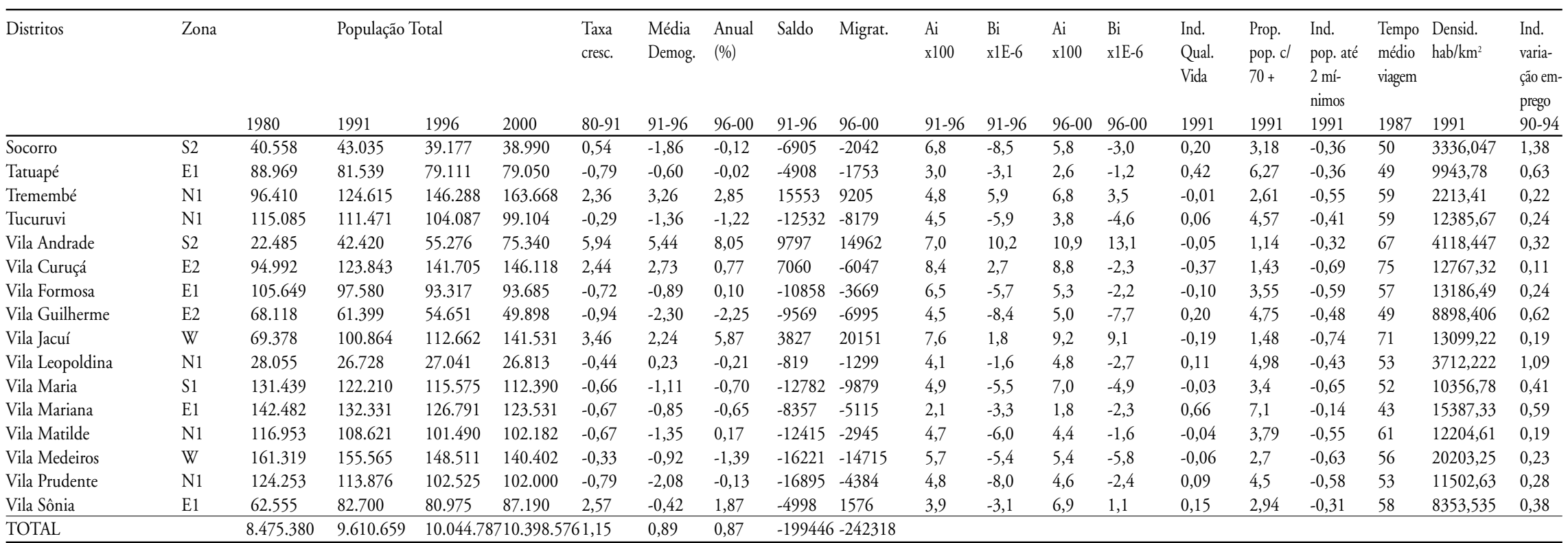

Fonte: Censos Demográficos 1991 e 2000; Contagem Populacional 1996; Sposati (1996); Prefeitura de São Paulo (www.prefeitura.sp.gov.br); Fundação Seade. 


\section{APÊNDICE GRÁFICO}

Divisão distrital do Município de São Paulo

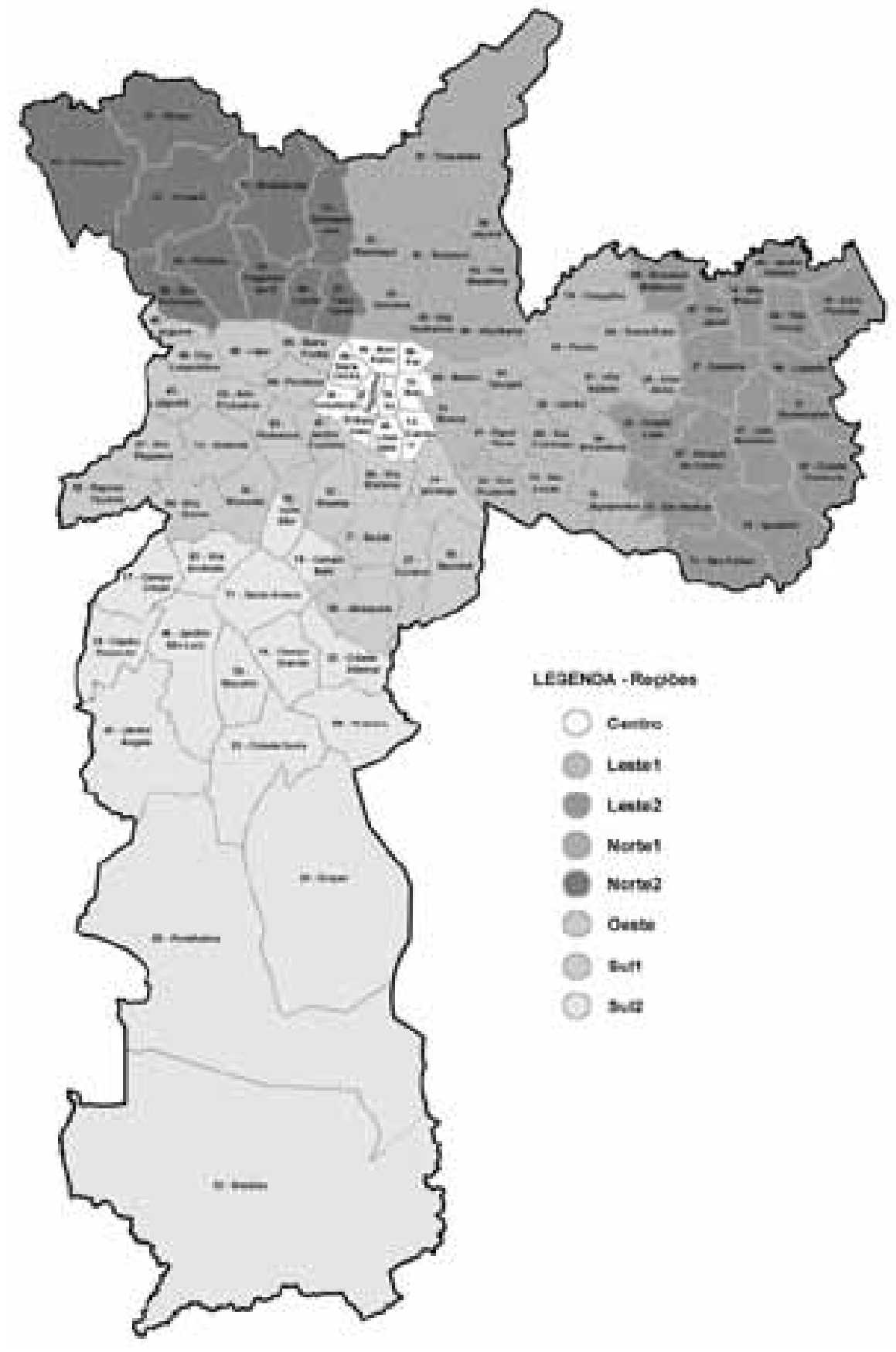


C R E S C I M E N T O U R B A N O, SA L D O S M I G R A T Ó R I O S

\section{REFERÊNCIAS BIBLIOGRÁFICAS}

BAENINGER, R. Região, metrópole e interior: espaços ganhadores e espaços perdedores mas migrações recentes - Brasil 1980-1996. Textos Nepo, 35, 2000.

BARBON, A. L. Mobilidade residencial intra-urbana em grandes centros: Regiäo metropolitana de São Paulo. Campinas, 2001. Relatório de Qualificação (Mestrado em Urbanismo) - PUC-Campinas.

BÓGUS, L. M. M.; TASCHNER, S. P. São Paulo: desigualdade e segregação. In: SESSÃO DE DEMOGRAFIA BRASILEIRA DA CONFERÊNCIA MUNDIAL DE POPULAÇÃO, Salvador, 2001.

CEPAM. Subsídios para elaboração do plano diretor. São Paulo: Fund. Faria Lima, 1990.

CORRADI, L. C. A et al. Divisão territorial da cidade e diferentes cenários populacionais: o caso de São Paulo. In: VII ENCONTRO NACIONAL DE ESTUDOS POPULACIONAIS. Anais... Abep, 1992. p.231-54.

CUNHA, J. M. P. Mobilidade populacional e expansão urbana: o caso da Região metropolitana de São Paulo. Campinas, 1994. Tese (Doutoramento) - Universidade de Campinas.

DAJOZ, R. Ecologia geral. Petrópolis: Vozes, 1983.

FARIA, T. C. Migração intra-urbana: uma síntese das teorias e modelos. II ENCONTRO NACIONAL SOBRE MIGRAÇÃO. Anais... Abep, 2000. p.421-40.

FARRET, R. et al. Dinâmica imobiliária e estrutura urbana: afinal, para que serviu a propriedade pública do solo em Brasília?. In: VI ENCONTRO NACIONAL DA ANPUR. Anais... Brasília: Anpur, 1995. p.451-8.

FREITAS, A. A. Segmentação do mercado imobiliário utilizando dados de preferência declarada. Florianópolis, 2000. Tese (Doutoramento em Eng. Produção) - Universidade Federal de Santa Catarina.

HERMANN, B. M. Um índice de qualidade de vida para São Paulo. I ENCONTRO DE ESTUDOS URBANOS E REGIONAIS. São Paulo, FGV, 2001. (Mimeo.).

JANNUZZI, P. M. Migração e mobilidade social: migrantes no mercado de trabalho paulista. Campinas: Autores Associados/Fapesp, 2000.

Evolução da renda e pobreza na Grande São Paulo nos anos 90: Evidências empíricas e outros subsídios para formulação de políticas de combate à indigência. Pesquisa \& Debate, São Paulo, 12(2):14-43, 2000.

JANNUZZI, P. M.; JANNUZZI, N. Projeção populacional para pequenas áreas: uso combinado do método das componentes demográficas e de sistema dinâmico em Ecologia. In: XII ENCONTRO NACIONAL DE ESTUDOS POPULACIONAIS. Caxambu: Anais... Caxambu, 2000. (CD-Rom.).

LAGO, L. C. Estruturação urbana e mobilidade espacial: alteraçôes no quadro de desigualdades sociespaciais na metrópole do Rio de Janeiro. In: XI ENCONTRO NACIONAL DE ESTUDOS POPULACIONAIS. Anais... Abep, 2000. p.383-419.

MARTINE, G. A redistribuição espacial da população brasileira durante a década de 80. Brasília: IPEA, 1994.

RICHARDSON, H. Economia urbana. Rio de Janeiro: Interciência, 1978.

ROLNIK, R. et al. São Paulo: crise e mudança. São Paulo: Brasiliense, 1990. . Folha explica: São Paulo. São Paulo: Publifolha, 2000.

SABOYA, R. T. Análises espaciais em planejamento urbano. Rev. Bras. Estudos Urbanos e Regionais, São Paulo, 3:61-79, 2000. 
PA U L O D E M A R T I O J A N N U Z Z I, N I C O L Á O J A N N U Z Z I

SMOLKA, M. O. Dinâmica populacional e estruturação intra-urbana: uma abordagem integrada da mobilidade através dos registros de transações imobiliárias. In: IX ENCONTRO NACIONAL DE ESTUDOS POPULACIONAIS. Anais... Abep, 1994, p.241-72.

SPOSATI, A. Mapa da exclusão/inclusão social da cidade de São Paulo. São Paulo: Educ, 1996.

SWARCWALD, C. L.; CASTILHO, E. A. Proposta de um modelo para desagregar projeções demográficas de grandes áreas em seus componentes geográficos. Revista de Saúde Pública, São Paulo, 23: 269-76, 1989.

TASCHNER, S. P. São Paulo 90: em busca de local onde morar. In: VI ENCONTRO NACIONAL DA ANPUR. Anais... Brasília: Anpur, 1995. p.509-17.

VALLADARES, L.; COELHO, M. P. La investigación urbana en América Latina : tendencias actualles y recomendaciones. Cadernos Ippur, Rio de Janeiro, X(1): 103-141, 1996.

A B S T R A C T This paper aims to contribute to the analysis of the recent changes on the regional population distribution in Sao Paulo city. It discusses the demographic growth trends of the 96 districts from 1980 through 2000 and the validity of radiocentric growth model, proposed late in the literature as the historical pattern of population distribution in the city during XX century. It brings, also, migration balances and residential attractiveness of the districts, computed through a demographic model. It shows some relationships between the demographic trends and urban and social factors, illustrating the effects of agglomeration diseconomies, poverty, the spread of commerce and buildings over the districts growth.

K E Y W O R D S Urban growth; residential mobility; São Paulo city; urban economy; migration. 